\title{
In North Carolina, It's Not Election Day-It's Election Month: An Analysis of the 2008 Election
}

\section{J. Michael Bitzer}

As one of the most competitive presidential contests in 2008, North Carolina also experienced a dramatic surge in early voting. While the literature regarding early voting presents conflicting findings, the opportunity to merge this area of study in voting behavior with the idea that "place matters" enables researchers to explore integrated questions about the activities and decisions of voters. By using a precinct-level analysis of urban, suburban, and rural voters in 2004 and 2008, this research begins an exploration of the impact of location and the opportunity to cast early ballots in turning a formerly red Republican state into a hue of a Tar Heel-blue state.

"Every jurisdiction that has introduced early voting agrees that once it has been started, it cannot be stopped. Voters love it."

(Federal Election Commission 1994, 4)

"Mr. Obama can write off Georgia and North Carolina ..."

(Schaller, July 1, 2008)

"We believed that from the outset that we had to expand the electorate or we were cooked."

(Plouffe 2009, 61)

In the span of four years, North Carolina went from being a solidly red Republican state in 2004 to one of the closest presidential contests in 2008, with the two major party candidates separated by less than 0.23 percent. With the discussion of the overwhelming ground game and strategy that the Obama campaign team assembled (Plouffe 2009; Panagopoulos and Francia 2009), the 2008 general election in the Tar Heel state provides political scientists and analysts a ripe field in which to analyze and revisit (or, in some case, visit for the first time) theories and ideas about political behavior. This study begins an investigation that combines two major threads of research - the idea that "place matters" and the impact of non-Election Day voting - by using precinct analysis of North Carolina in 2008. By researching the differences between urban, suburban, and rural voters in a highlycompetitive and contested state, particularly through the use of early voting (both with absentee and one-stop voting in North Carolina), a greater understanding can be had of the role and effect of liberalized voting set within the

J. MICHAEL BITZER is an associate professor of political science and history at Catawba College.

The American Review of Politics, Vol. 31, Fall, 2010: 223-244

(C)2010 The American Review of Politics 
context of political location. Through the analysis of voter registration and ballots cast in over 2,600 precincts in the Tar Heel State, this research will present some preliminary findings that can lead to further analysis and a more comprehensive understand of issues surrounding political behavior.

\section{Voting Early and on Election Day}

The use of early voting has grown over time within the states, with the often-expressed desire of giving citizens increased opportunities to vote, thereby increasing voter turnout. In addition to the typical early voting method of mail-in ballots, the state of Texas began to allow citizens to cast votes in person prior to the General Election Day in 1991. Since the Longhorn State's use of early voting ballots, several states have adopted the same innovation, including North Carolina, where citizens can cast their ballots up to three weeks prior to the General Election Day (NC State Board of Election website). In this system, NC voters may go to their county board of elections office to cast their ballot during regular business hours in these three weeks; many counties utilized other voting locations for early voting and state law allows voting to occur on the Saturday prior to General Election Day. Only eight states currently do not offer any form of "early voting," according to the League of Women Voters (Vote411.org website). The other states - along with the District of Columbia-have a variety of approaches to early voting, from using an absentee voting process to no-excuse voting 45 days prior to the election (see Appendix for specifics on each state's early voting standards).

This use of early voting has been part of a focus by scholars who investigate the effects of participation on turnout in American politics. Even before the American Revolution, voters were allowed to cast their ballots by either "absentee" or "proxy voting, typically to allow colonial farmers the chance to cast their ballots" (Dubin and Kalsow 1996, 372). Yet as voting restrictions have eased while education levels have increased, voter turnout has dropped; since 1960, when voter turnout was 62.77 percent, the percentage of citizens turning out has steadily declined (Hill 2006, 3). A variety of explanations has been developed to explain theoretically and empirically why voter turnout is at this level in the United States when compared to other democratic nations. From an institutional perspective (Hill 2006) to one based on the costs to voters outweighing the potential impact of their singular vote (Rosenstone and Hansen 1993), turnout has been a critical focus of understanding political behavior. With the easing of voter restrictions (from registration laws to voting by mail, along with early voting), the research on participation through voting centers on a variety of aspects, including who votes, why do they vote, and the consequences of the act of 
voting. One aspect that has garnered recent focus has been the increased opportunity to cast ballots, notably through absentee and early voting laws adopted by states.

With this early voting convenience, researchers have begun to investigate the various impacts and effects of relaxing the requirement to cast ballots on certain days and at certain times. In some of the early work done by political scientists on this phenomena, a number of conclusions have been made about the impact and effect of early voting. Much of the work focuses on absentee voting, such as Patterson and Caldeira's (1985) findings that in two states (California and Iowa), those casting absentee ballots are older, have higher levels of income, and live in urban settings. Another effect surrounding the use of absentee voting is that when political parties seek to mobilize and target potential early voters, absentee ballot use increases (Oliver 1996; Patterson and Caldeira 1985). In examining California's absentee versus precinct voting patterns, Dubin and Kalsow (1996) found that from 1962 to 1994, the impact of a 1977 liberalization law regarding absentee ballots did have an impact on primary elections by increasing political participation, but that the effect on general elections differs "since absentee and precinct voting are substitute activities in general elections" (388). In addition, their findings contradicted Patterson and Caldeira's (1985) findings regarding a positive relationship between higher incomes and absentee voting. One of the key questions left by Dubin and Kalsow centered on the political behavior of these different types of voters: "do [early/absentee voters] indeed vote similar to their precinct counterparts, or are their vote patterns significant different?" $(1996,389)$.

In an analysis of Texas' use of early and absentee voting in 1992, Stein and Garcia-Monet found that voter turnout increases, albeit modestly, and that "partisan efforts to mobilize newly registered voters through early voting has significant, but weak, electoral benefits" (1997, 658). The ClintonGore campaign focused its energies on Texas counties with large Hispanic populations and that focus saw large increases in voter registration; in their analysis, Stein and Garcia-Monet (1997) found that a one percent increase in the adult Hispanic population was associated with a .1 percent increase in early-cast votes. A greater increase (.24\%) in early-cast votes was found when a county saw a one percent increased in voter registration from the previous presidential election year (1988 to 1992). Further analysis demonstrated that median home value was positively related to votes cast early, but that the number of early voting locations was unrelated to early voting itself.

Stein's 1998 research investigated Dubin and Kalsow's question on the political behavior of different types of voters and found significant differences "between election-day and early voters." While no political candidate 
in the senatorial or gubernatorial elections in the November 1994 Texas general election benefitted from early voting, Stein (1998) did find that early voters were more strongly partisan, poorer, older, more conservative, more likely to report an interest in politics, and more likely to be males than election-day voters; no racial or ethnic differences, nor education levels, were revealed in the composition of early versus election-day voters. Party identification was shown to be the strongest predictor of vote choice, and when combined with when a ballot was cast, had a significant independent effect on vote choice. Stein contends that attitudinal distinctions, rather than demographic traits, demonstrate the sharpest differences between early voters and election-day voters. When it came to using Patterson and Caldeira's (1985) mobilization thesis, however, Stein's findings were that early voters were equally likely to be of either major political party.

Using political party preference as an emphasis in the research on early voting has lead to some conflicting findings. In looking at the effects of party activity and eligibility restrictions on absentee voting, Oliver (1996) suggested that Republicans used absentee voting opportunities as a way to mobilize their supporters to register and cast their ballots. Yet in their analysis, Karp and Banducci find "little support for the hypothesis that absentee voting depends on mobilization" $(2001,188)$ and that only age and education make a voter more likely to cast their ballot before the designated Election Day. In addition, when it comes to encouraging those among groups who are significantly less likely to vote on Election Day, early voting and absentee laws has little positive effect on groups such as non-Whites and independent partisans. While Oliver (1996) believed that Republicans would be the main beneficiaries of the use of early and absentee voting, Karp and Banducci believe that, "all things being equal, the Republican bias discovered by others may have been due more to self-selection than mobilization" (2001, 191).

Further studies of absentee and early voting have been conducted by Neeley and Richardson (2001) and Barreto et al. (2006). In their study of one Tennessee county through the use of a phone survey of both early and regular day voters, Neeley and Richardson (2001) posed several hypotheses, most notably whether early voters differed from regular day voters on key attitudinal and socioeconomic traits. Again, like previous findings, Neeley and Richardson find "no confirming evidence of a mobilization effect"; in fact, attitudinal variables "weakly support the explanation that early voting was more a convenience for voters who would have been likely to vote anyway" $(2001,389)$. None of the socioeconomic variables - such as age, income, race, or education-indicated that early voting mobilized voters who would not normally turn out to cast ballots. Early voting was seen as a convenience for those politically interested citizens who would have shown 
up to the polls in any event. In their study (using survey and exit poll results) of absentee voters versus Election Day voters in California, Barreto et al. find an absentee electorate "that is growing and heterogeneous in terms of experience and reason for voting absentee, suggesting no specific partisan bias" $(2006,230)$. The greatest difference between those casting votes early compared to those casting on Election Day centered on age and education, with absentee voters being "considerably older and better educated than polling place voters" $(2006,231)$.

\section{Place Matters: Urban vs. Suburban vs. Rural Precincts}

Given the overall discussion of red states, blue states, and purple states (see Abramowitz and Saunders 2005; Bartels 2006; Fiorina et al. 2010; Flanigan and Zingale 2010; Oppenheimer 2005; Teixeira 2008; McCarty et al. 2006), political scientists have just recently begun investigating the impact of place on political behavior, specifically as urban, suburban, and rural settings impact (and are impacted by) political behavior. If one is to believe recent work by Bishop and Cushing, America has engaged in a "big sort," "a thirty-year movement toward more homogeneous ways of living - that the polarization so apparent in the way political leaders talked was reflected in the way Americans lived" (2008, 11).

Using the idea that "place matters" (Dreier et al. 2004; Gimpel and Schuknecht 2004) in studying political behavior has become the subject of recent study, particular related to urban, suburban, and rural voting behavior. Most research on urban, suburban, and rural voting patterns share a common thread: urban voting behavior is "one of the most important, but least understood, topics in the voting literature" (Lieske 1989, 150), while those who study suburban voting behavior "know little about how democracy operates in these locales or how their unique social composition affects their political life" (Oliver and Ha 2007, 393), and when it comes to rural voters, scholars "have contributed very little (exceptions include Francia and Baumgartner 2006; Gimpel and Karnes 2006) to the debate by way of examination of the voting behavior of rural voters" (McKee 2007, 1). Typically, these studies tend to focus only on one of the three areas, though a recent study by McKee and Teigen (2009) incorporated all three areas within an analysis of voting behavior, and Gainsborough (2005) compared cities and suburbs in an analysis of presidential voting. But for the most part, as units of analysis, the typical approach to studying political behavior at the local level-whether it be in an urban, suburban, or rural setting - is limited to the particular setting.

Using a major urban area's elections over time (Cincinnati) as his analysis, Lieske found that in urban environments, "the strongest correlate of 
the candidate vote totals is the size of their political following" $(1989,167)$ defined as being the vote total in a candidate's most recent try for public office. Thus, Lieske concludes that in urban areas, "electoral success is heavily dependent on the fidelity, size, and composition [particularly the racial and partisan] of their respective political followings," and that "these findings suggest the value of persistence in local politics" $(1989,168)$.

Like the work done on urban voting behavior, recent work on suburbanization by Thomas (1998), Gainsborough (2001, 2005), McKee and Shaw (2003), and Oliver (2001; with Ha, 2007) has sought to investigate the behavior and political beliefs of those Americans, fifty percent of whom now reside in a suburbanized America (Oliver and Ha 2007, 393). With half of the American population now living in suburban areas, the impact of suburban residents on elections and public policy are ripe for study by political scientists. This population, and its related political behavior, is critical to understanding the dynamics of the American political landscape, and yet, "many of [suburbanization's] political implications are not well understood" (Oliver 2003, 312) due to the fact that political scientists have "largely ignored the relationship between modern suburbs and political behavior" (Gainsborough 2001, 3). In their seminal work, Campbell et al. noted that "in the classic contemporary example, the working man moves to the suburbs as a Democrat, but there associates with Republicans and with greater or lesser speed takes on Republican characteristics" (1960, 443). Wirt et al. (1971) focused their study specifically on suburban political behavior during the 1948-1964 presidential elections, and noted that by the Nixon-Kennedy election, "the sheer size of the suburban electorate overtook that of their core cities" (1971, 58). Nevertheless, there was relatively little difference between both urban and suburban voting patterns.

More recently, others have sought to explain the behavior of suburban voters within the suburban context. McGirr's 2001 study of the "suburban warrior" documents the origins within California's suburbs of a growing conservative movement in the 1960s that lead to a reconfigured Republican Party and national political landscape. In a study utilizing 1990 Census data, Gainsborough (2001) presents empirical evidence that focuses on the differentiation between urban and suburban voters, most notably that "city and suburban residents do not respond in the same ways to a shared metropolitan environment" (137). Within her study, Gainsborough found that, all other factors held constant, suburban voters in more homogeneous areas tended to be more Republican and supportive of Republican candidates. Gainsborough recognized that without some commonality between the two areas, the political landscape will result in "the continuing balkanization of America" (2001, 140) between suburban and urban voters. 
In an expansive study of suburbanization, Oliver (2001) investigated whether suburbanization achieves the dream of participation within civic society and how this is reflected within governing institutions. His findings demonstrate that while suburbanization does influence civic life and participation within America, suburbanization can actually demobilize citizens from the political realm by promoting political conflict and separation (188). Oliver expands the traditional approach to identifying political participation from just voting to other activities, such as contacting officials, attending community board meetings, participating in voluntary organizations, and working informally with one's neighbors.

The last of the three distinct localities, rural America, has begun to serve not only as a focus of scholarly research, but of party strategists as well. With the significant electoral margins in rural and small-town voters by George W. Bush, rural voters served notice that their perceptions and ideas about politics put them into a distinct category, when compared to their urban and suburban counterparts (Toner 2004). Gimpel and Karnes find that the "profile of rural America contains potential cross-pressures," in that they are "morally and socially conservative, but they might also have good reasons to vote with the Democrats on matters of economic import" (2006, 467). In his analysis of presidential elections from 1992-2004, McKee validates the growing Republicanism in rural America when compared to non-rural voters, based on "a range of demographic, religious, political, and election-specific factors" (21). While this growing GOP territory has the potential for Republican advantages, McKee (2007) notes that presidential candidates can not afford to ignore issues important to rural voters, in that Bill Clinton was able to neutralize the rural vote while George W. Bush was able to secure his presidential victories with rural landslides in comparison to lower non-rural support. In their research on the impact of all three regions (urban, suburban, and rural), McKee and Teigen (2009) again find confirmation that the more urban a county, the less support Republican candidates will garner.

In their analysis of the 2004 presidential election, Abramson et al. note that it "has been well established that Republicans have been doing better in suburban and rural areas" $(2006,113)$ and have continued to do so, with Kerry only receiving 40 percent of white suburban votes, according to NES Survey data. In comparison, the Democrat received 51 percent of white urban votes. In the 2008 exit polls, Obama received half of the national suburban vote and continued the domination in the urban areas, winning 63 percent. McCain was only able to secure 35 percent of the national urban vote, while garnering 48 percent of the suburban vote and 53 percent of the rural vote nation-wide. 


\section{Urban, Suburban, and Rural Voters in the North Carolina 2008 General Election}

This study utilizes the 2008 General Election returns in the state's urban, suburban, and rural precincts. V.O. Key in his classic work, Southern Politics in State and Nation, asserts that the Tar Heel State has been seen as "a closer approximation to national norms, or national expectations of performance, than they find elsewhere in the South" $(1986,205)$. With its modern-day significant population growth, racial composition, and the economy that has experienced both growth in technology (with the Research Triangle) and the loss of manufacturing jobs (especially textiles and furniture), North Carolina can be seen as a representative state of the South, leading it to serve as a viable candidate for political analysis (see Knotts 2005; Francia and Baumgartner 2005). Both in 2000 and 2004, North Carolina was solidly a red state, giving George W. Bush a win of thirteen and twelve percentage points respectively. With the change in the nation's mood and economic conditions worsening, the Democratic presidential campaign of Barack Obama believed that North Carolina could be a realistic target for its mobilization efforts in reshaping the political map of the United States. Using a state that had gone from a solidly Republican presidential state to one decided almost a week after the General Election by less than one percent might mean that the generalizability of the findings could be compromised; however, single-state research designs allow for exploration of specific phenomenon, such as cultural and structural contents (NicholsonCrotty and Meier 2002). With 100 counties representing a variety of urban, suburban, and rural patterns, North Carolina presents a suitable state-level case study for analysis when it comes to combining the idea that "place matters" with the use of early voting and Election Day voting patterns. In addition, North Carolina, as in 27 other states, requires party registration for voters (Democratic, Republican, and Unaffiliated), providing an opportunity to control for party identification within the analysis. ${ }^{1}$ With 99 of the 100 counties reporting their election results by precinct and by the type of vote cast (one-stop/early versus Election Day), North Carolina provides a unique opportunity for basic descriptive analysis into the use of early voting versus Election Day voting. ${ }^{2}$

\section{Hypotheses}

This study seeks to combine two important areas within the literature on voting behavior: the differences between urban, suburban and rural precincts and the impact and effect of early voting compared to voting on 
Election Day. With the increased mobilization by the Democratic Party, it would be expected that a number of hypotheses would focus on this aspect of the 2008 election in North Carolina. Specifically:

$\boldsymbol{H}_{1}:$ Mobilization effect benefits Democrats over Republicans in the 2008 North Carolina presidential election.

$\boldsymbol{H}_{2}:$ Registration increases benefit Democrats over Republicans.

$\boldsymbol{H}_{3}$ : Black registration and voting increases due to a black Democratic presidential candidate.

$\boldsymbol{H}_{4}$ : Republican candidates for president, U.S. Senate, and gubernatorial races see their overall percentages drop from 2004 to 2008 in urban and suburban precincts.

$\boldsymbol{H}_{5}$ : Democrats see a corresponding increase of support from 2004 to 2008, particularly in urban and suburban precincts.

$\boldsymbol{H}_{6}:$ More voters at the presidential level cast early ballots than on Election Day.

$\boldsymbol{H}_{7:}$ Urban precincts see a greater percentage of votes cast early than suburban precincts.

$\boldsymbol{H}_{8}:$ The impact of the racial demographics of a precinct will have be significantly related to the percentage of Democratic votes in the precinct, along with partisan and mobilization factors.

\section{Data and Analysis}

Each North Carolina county reported its Election Day and early voting totals by precinct, along with each precinct's voter registration totals by party identification, racial and Hispanic/Non-Hispanic composition, and gender. This analysis presents several basic descriptive findings utilizing this dataset followed by a multivariate model incorporating relevant variables to predict Democratic vote percentages across precincts. In this study, 2662 precincts were identified and used, with 21.5 percent categorized as urban, 30.3 percent categorized as suburban, and 48.2 percent classified as rural precincts. By using the Census Bureau's definition and classification of urban and suburban areas, this study follows Gainsborough's approach to studying suburban political behavior by classifying suburban areas as the "non-central-city portion of the metropolitan area" (2001, 35-36). While many researchers have utilized county-level data for research purposes, this study utilizes precinct-level data. Despite the fact that many central cities within various NC metropolitan areas constitute a large portion of their home county, some precincts lie outside of the central city's limits; thus it would be inaccurate to utilize county-level data when attempting to decipher 
urban and suburban voting patterns. For example, in Mecklenburg County, the City of Charlotte includes 164 precincts; however, 24 precincts are outside of Charlotte's city limits and are in cities or towns such as Cornelius, Davidson, Huntersville, Matthews, Mint Hill, and Pineville, or unincorporated areas of Mecklenburg County. Most local political commentators would consider these cities/towns as "suburban." This study will label the precincts outside of the central city (but within the central city's county), as well as those counties adjacent and incorporated into the Census Bureau's metropolitan area (such as Gastonia and Monroe adjacent to Charlotte), as "suburban." Those precincts within the city limits will be classified as "urban." To confirm whether a precinct lies within or outside a central city's limits, the mayoral election results for a central city will be used to help classify a precinct as urban or suburban. The remaining counties and their precincts, outside of the metropolitan areas, are classified as rural precincts.

This dataset can be compared to the exit polls conducted in North Carolina in 2008 as a baseline estimate. According to exit polls, urban voters made up 29 percent of the voters, casting their ballots 66 percent for Obama to 34 percent for McCain. In the suburban areas of North Carolina, making up 27 percent of the total voters, McCain was able to beat Obama by ten points (54 to $44 \%$ ), while in the rural areas (constituting $44 \%$ of the total voters) it was a thirteen point advantage for McCain, 56 to 43 percent (CNN website).

Overall turnout in North Carolina in 2008 was 69.93 percent (NC State Board of Elections website). Of that nearly 70 percent voter turnout, 42 percent of the votes were cast before November 4, 2008, with the remaining 58 percent cast on Election Day. Based on statistical analysis conducted by the State Board of Elections, 51 percent of all non-Election Day ballots were cast by registered Democrats, with 30 percent coming from registered Republicans and 18 percent from Unaffiliated registered voters. Comparing the non-Election Day votes cast to party registration data, 48 percent of all registered Democrats cast an early ballot, while 40 percent of registered Republicans and 35 percent of registered Unaffiliated voters cast early ballots. When it comes to racial demographics, 57 percent of registered black voters cast their ballots early, compared to only 40 percent of registered white voters casting early ballots.

After classifying the precinct-level data into one of three classifications (urban, suburban, and rural), I ran a number of descriptive analyses to explore some of the hypotheses generated above. First, registered voters in urban precincts constituted 25.7 percent of all registered voters in 2008, while suburban voters made up 33.7 percent and rural voters constituted 40.6 percent of the registered voters in 2008 . When it comes to actual votes cast in the 2008 presidential contest, urban precincts accounted for 25 percent of 
all votes cast, while suburban votes accounted for 34.7 and rural votes accounted for 39.6 percent, respectively. Comparing 2008 urban and suburban precincts to their 2004 numbers, we see growth in all but Republican voter registration figures (see Table 1). Republicans lost registered voters in urban precincts, while Democrats and, more so, Unaffiliated registered voters increased their total numbers. Looking at the composite makeup within urban precincts, Republicans lost five percent of their registered numbers in 2008 when compared to 2004. Registered Democrats increased their percentage from 2004 to 2008 within urban precincts, with Unaffiliated registered voters increasing their percentage of all urban precincts to make up nearly one-quarter of all urban voters. Within suburban precincts, when compared to 2004, registered Democratic voters held a slight plurality over Republican registered voters in 2008, with Unaffiliated registered voters growing in size within suburban precincts. A similar set of numbers for rural precincts in 2004 is not yet available, but one can note that registered Democrats make up a significant plurality in this Republican region of rural North Carolina; of course, one must also note the perhaps continuing presence of a notable phenomenon in North Carolina politics, that of the "Jessecrat," a registered Democrat who votes Republican at the federal office level and yet returns home for state offices. It would be instructive to determine the effect of the May 2008 presidential primary on the subsequent general election totals. With a competitive presidential primary between Barack Obama and Hillary Clinton, while the Republican presidential primary was all but wrapped up for John McCain, did North Carolinians switch their party registrations from Republican to Unaffiliated or Democratic to participate in the sole competitive presidential primary?

What of the racial composition of voter registration in the three types of precincts? According to the North Carolina State Board of Elections, 967,804 new registrations were reported for the period January 1 to November 2, 2008, with 67 percent being net registration (meaning that if a voter moved from one NC county to another, they would be counted as one new and one removed). Black voter registration was 31 percent of the total number of registrations, with whites composing 56 percent of new registrations. Table 2 reports the 2004 and 2008 mean percentages for white and black in the state and the three precinct types:

Table 3 compares the 2004 and 2008 vote totals garnered by Republican candidates in the three areas: urban, suburban, and rural precincts. The numbers show the weakness of the Republican presidential candidate and U.S. senatorial in 2008 when compared to 2004. Only the Republican gubernatorial candidate, Charlotte mayor Pat McCrory, performed better than his Republican predecessor did statewide and in the urban and suburban precincts. 
Table 1. Voter Registration in Urban and Suburban Precincts, 2004 to 2008, and in Rural Precincts in 2008 (percentages below the raw numbers indicate the party percentage within the type of precinct)

\begin{tabular}{|c|c|c|c|}
\hline & 2004 & 2008 & $\begin{array}{l}\text { \% Change from } \\
2004 \text { to } 2008\end{array}$ \\
\hline Urban Registered Democrats & $\begin{array}{c}706,908 \\
(50 \%)\end{array}$ & $\begin{array}{c}786,225 \\
(52 \%)\end{array}$ & $11.2 \%$ \\
\hline Urban Registered Republicans & $\begin{array}{c}404,963 \\
(29 \%)\end{array}$ & $\begin{array}{c}367,869 \\
(24 \%)\end{array}$ & $-9.1 \%$ \\
\hline Urban Registered Unaffiliated & $\begin{array}{c}287,217 \\
(20 \%)\end{array}$ & $\begin{array}{c}355,521 \\
(23 \%)\end{array}$ & $23.7 \%$ \\
\hline Suburban Registered Democrats & $\begin{array}{c}706,284 \\
(40 \%)\end{array}$ & $\begin{array}{c}778,923 \\
(39 \%)\end{array}$ & $10.2 \%$ \\
\hline Suburban Registered Republicans & $\begin{array}{c}699,136 \\
(40 \%)\end{array}$ & $\begin{array}{c}732,966 \\
(37 \%)\end{array}$ & $4.8 \%$ \\
\hline Suburban Registered Unaffiliated & $\begin{array}{c}349,142 \\
(20 \%)\end{array}$ & $\begin{array}{c}472,006 \\
(24 \%)\end{array}$ & $35.1 \%$ \\
\hline Rural Registered Democrats & $\mathrm{n} / \mathrm{a}$ & $\begin{array}{c}1,110,975 \\
(47 \%)\end{array}$ & \\
\hline Rural Registered Republicans & $\mathrm{n} / \mathrm{a}$ & $\begin{array}{c}795,408 \\
(33 \%)\end{array}$ & \\
\hline Rural Registered Unaffiliated & $\mathrm{n} / \mathrm{a}$ & $\begin{array}{c}479,404 \\
(20 \%)\end{array}$ & \\
\hline
\end{tabular}

Table 2. Mean Percentages of White and Blacks Registered Voters Statewide and in Urban, Suburban, and Rural Precincts, 2004 and 2008

\begin{tabular}{lcccc}
\hline & \multicolumn{2}{c}{ White Registered Voters } & \multicolumn{2}{c}{ Black Registered Voters } \\
& 2004 & 2008 & 2004 & 2008 \\
\hline Statewide Totals & $77 \%$ & $73 \%$ & $20 \%$ & $21 \%$ \\
Urban Precincts & $69 \%$ & $63 \%$ & $31 \%$ & $30 \%$ \\
Suburban Precincts & $85 \%$ & $79 \%$ & $14 \%$ & $15 \%$ \\
Rural Precincts & $*$ & $71 \%$ & $*$ & $20 \%$ \\
*Rural precincts data for 2004 is not available. & & & \\
\hline
\end{tabular}


Table 3. Mean Percentages of Votes Cast for Republican Candidates in North Carolina's Urban, Suburban, and Rural Precincts, 2004 and 2008

\begin{tabular}{lcccccc}
\hline & \multicolumn{2}{c}{ President } & \multicolumn{2}{c}{ U.S. Senate } & \multicolumn{2}{c}{ Governor } \\
& 2004 & 2008 & 2004 & 2008 & 2004 & 2008 \\
\hline Statewide Totals & $56.2 \%$ & $50 \%$ & $52.3 \%$ & $46 \%$ & $43.5 \%$ & $47 \%$ \\
Urban Precincts & $42.9 \%$ & $32 \%$ & $39.9 \%$ & $31 \%$ & $33.9 \%$ & $38 \%$ \\
Suburban Precincts & $62.7 \%$ & $55 \%$ & $58.5 \%$ & $50 \%$ & $47.5 \%$ & $53 \%$ \\
Rural Precincts & $*$ & $56 \%$ & $*$ & $49 \%$ & $*$ & $48 \%$ \\
* Rural precincts data for 2004 is not available. & & & & \\
\hline
\end{tabular}

Table 4 presents the changes in party affiliation within urban precincts in the eight metropolitan areas from 2004 to 2008. The most notable aspects of this table are the changes in unaffiliated registration, ranging from +3 in Winston-Salem and Greensboro to +8 in Asheville. This same trend in unaffiliated voters occurred in the suburban precincts as well (see Table 5), with four metropolitan areas (Asheville, Winston-Salem, Raleigh, and Wilmington) seeing their unaffiliated voters in suburban precincts increase by five percentage points.

Turning to general election results, 2008 should witness a greater percentage of votes going to Barack Obama than John Kerry received, perhaps due to the mobilization effort that the Obama campaign put together. Table 6 presents the changes from 2004 to 2008 in the percentage that the Democratic presidential candidates received in urban precincts. Most notably, the

\section{Table 4. Voter Registration Percentages within Metropolitan Areas in North Carolina: Urban Precincts}

\begin{tabular}{lccccccccc}
\hline & \multicolumn{3}{c}{$\begin{array}{c}\text { Democratic } \\
\text { Registration }\end{array}$} & \multicolumn{3}{c}{$\begin{array}{c}\text { Republican } \\
\text { Registration }\end{array}$} & \multicolumn{3}{c}{$\begin{array}{c}\text { Unaffiliated } \\
\text { Registration }\end{array}$} \\
& 2004 & 2008 & $\%$ Change & 2004 & 2008 & $\%$ Change & 2004 & $2008 \%$ Change \\
\hline Asheville & 51 & 53 & +2 & 23 & 18 & -5 & 21 & 29 & +8 \\
Winston- & & & & & & & & & \\
Salem & 53 & 54 & -1 & 29 & 26 & -3 & 16 & 19 & +3 \\
Greensboro & 53 & 54 & +1 & 29 & 24 & -5 & 17 & 20 & +3 \\
Durham & 60 & 59 & -1 & 18 & 15 & -3 & 21 & 24 & +3 \\
Raleigh & 47 & 48 & +1 & 30 & 27 & -3 & 20 & 24 & +4 \\
Charlotte & 47 & 48 & +1 & 31 & 27 & -4 & 20 & 24 & +4 \\
Fayetteville & 54 & 52 & -2 & 26 & 25 & -1 & 18 & 22 & +4 \\
Wilmington & 48 & 47 & -1 & 28 & 25 & -3 & 22 & 26 & +4 \\
\hline
\end{tabular}


Table 5. Voter Registration Percentages within Metropolitan Areas in North Carolina: Suburban Precincts

\begin{tabular}{lccccccccc}
\hline & \multicolumn{3}{c}{$\begin{array}{c}\text { Democratic } \\
\text { Registration }\end{array}$} & \multicolumn{3}{c}{$\begin{array}{c}\text { Republican } \\
\text { Registration }\end{array}$} & \multicolumn{3}{c}{$\begin{array}{c}\text { Unaffiliated } \\
\text { Registration }\end{array}$} \\
& 2004 & 2008 & $\%$ Change & 2004 & 2008 & $\%$ Change & 2004 & $2008 \%$ Change \\
\hline Asheville & 41 & 40 & -1 & 36 & 33 & -3 & 21 & 26 & +5 \\
$\begin{array}{l}\text { Winston- } \\
\text { Salem }\end{array}$ & 32 & 30 & -2 & 51 & 50 & -1 & 15 & 20 & +5 \\
Greensboro & 40 & 38 & -2 & 42 & 40 & -2 & 17 & 21 & +4 \\
Durham & 55 & 57 & +2 & 26 & 23 & -3 & 18 & 19 & +1 \\
Raleigh & 42 & 41 & -1 & 37 & 33 & -4 & 19 & 24 & +5 \\
Charlotte & 39 & 38 & -1 & 40 & 38 & -2 & 19 & 22 & +3 \\
Fayetteville & 55 & 54 & -1 & 25 & 23 & -2 & 19 & 21 & +2 \\
Wilmington & 43 & 40 & -3 & 37 & 36 & -1 & 18 & 23 & +5 \\
\hline
\end{tabular}
Table 6. Presidential Vote Percentage within Metropolitan Areas
in North Carolina: Urban Precincts

\begin{tabular}{lcccccc}
\hline & \multicolumn{3}{c}{$\begin{array}{c}\text { Democratic Presidential Vote \% } \\
\text { \% }\end{array}$} & \multicolumn{3}{c}{ Republican Presidential Vote \% } \\
& 2004 & 2008 & \% Change & 2004 & 2008 & \% Change \\
\hline Asheville & 63 & 76 & +13 & 36 & 24 & -12 \\
Winston-Salem & 57 & 66 & +9 & 42 & 33 & -9 \\
Greensboro & 56 & 67 & +11 & 43 & 32 & -11 \\
Durham & 71 & 76 & +5 & 28 & 23 & -5 \\
Raleigh & 54 & 62 & +8 & 45 & 37 & -7 \\
Charlotte & 55 & 67 & +12 & 44 & 32 & -12 \\
Fayetteville & 53 & 59 & +6 & 46 & 40 & -6 \\
Wilmington & 59 & 63 & +4 & 40 & 36 & -4 \\
\hline
\end{tabular}

urban precincts in Asheville, Charlotte, and Greensboro saw double-digit percentage point changes $(13,12$, and 11 point increases over 2004); all other metropolitan area urban precincts saw single-digit percentage increases. McCain saw Republican support in urban precincts decline substantially when compared to the percentage Bush received in 2004, ranging from 40 percent in Wilmington to only 23 percent in Durham. Table 7 indicates Obama increasing his suburban percentages over Kerry's performance in 2004, with the lone exception being in Durham, which saw a four percent decrease in the level of suburban support for the Democratic presidential candidate. 


\section{Table 7. Presidential Vote Percentage within Metropolitan Areas in North Carolina: Suburban Precincts}

\begin{tabular}{lcccccc}
\hline & \multicolumn{3}{c}{$\begin{array}{c}\text { Democratic Presidential Vote \% } \\
\text { \% }\end{array}$} & \multicolumn{3}{c}{ Republican Presidential Vote \% } \\
& 2004 & 2008 & \% Change & 2004 & 2008 & \% Change \\
\hline Asheville & 39 & 46 & +7 & 60 & 53 & -7 \\
Winston-Salem & 28 & 34 & +6 & 71 & 66 & -5 \\
Greensboro & 37 & 41 & +4 & 62 & 58 & -4 \\
Durham & 50 & 46 & -4 & 49 & 53 & +4 \\
Raleigh & 39 & 49 & +10 & 60 & 51 & -9 \\
Charlotte & 34 & 43 & +9 & 65 & 56 & -9 \\
Fayetteville & 49 & 58 & +9 & 50 & 41 & -9 \\
Wilmington & 40 & 42 & +2 & 59 & 57 & -2 \\
\hline
\end{tabular}

The final set of descriptive analyses, reported in Table 8 , divides the ballots cast at the presidential level between Election Day percentages versus those cast before Election Day (early) percentages. In all urban precincts, voters chose to cast their ballots before November 4, 2008; and in all but one metropolitan area (Winston-Salem), early ballots made up the majority of ballots cast in suburban precincts. Asheville urban precincts saw the highest percentage of ballots cast early (77\%), while Wilmington had the lowest urban precinct percentage, with only 52 percent of ballots cast early. In the suburban precincts, ironically, Wilmington had 64 percent of its ballots cast early, while Winston-Salem suburban precincts saw a majority of its ballots cast on Election Day.

Table 8. Early vs. Election Day Presidential Ballots Cast within Metropolitan Areas in North Carolina (bolded cells indicate more ballots cast on Election Day than through early methods)

\begin{tabular}{|c|c|c|c|c|}
\hline & \multicolumn{2}{|c|}{ Urban Precincts } & \multicolumn{2}{|c|}{ Suburban Precincts } \\
\hline & $\begin{array}{l}\% \text { Ballots } \\
\text { Cast Early }\end{array}$ & $\begin{array}{l}\% \text { Ballots Cast } \\
\text { on Election Day }\end{array}$ & $\begin{array}{l}\% \text { Ballots } \\
\text { Cast Early }\end{array}$ & $\begin{array}{r}\% \text { Ballots Cast } \\
\text { on Election Day }\end{array}$ \\
\hline Asheville & 77 & 23 & 60 & 40 \\
\hline Winston-Salem & 57 & 46 & 46 & 54 \\
\hline Greensboro & 68 & 32 & 59 & 41 \\
\hline Durham & 75 & 25 & 64 & 36 \\
\hline Raleigh & 62 & 38 & 57 & 43 \\
\hline Charlotte & 53 & 47 & 55 & 45 \\
\hline Fayetteville & 61 & 39 & 58 & 42 \\
\hline Wilmington & 52 & 48 & 64 & 36 \\
\hline
\end{tabular}


Table 9. Early vs. Election Day Percentages of Ballots Cast for President within Metropolitan Areas in North Carolina (bolded cells indicate more ballots cast on Election Day than through early methods)

\begin{tabular}{|c|c|c|c|c|c|c|c|c|}
\hline & \multicolumn{4}{|c|}{ Urban Precincts } & \multicolumn{4}{|c|}{ Suburban Precincts } \\
\hline & \multicolumn{2}{|c|}{ Obama_- } & \multicolumn{2}{|c|}{-McCain- } & \multicolumn{2}{|c|}{-Obama- } & \multicolumn{2}{|c|}{ McCain- } \\
\hline & & Election & & Election & & Election & & Election \\
\hline & Early & Day & Early & Day & Early & Day & Early & Day \\
\hline Asheville & 80 & 20 & 66 & 34 & 67 & 33 & 54 & 45 \\
\hline Winston-Salem & 63 & 37 & 46 & 54 & 54 & 46 & 42 & 58 \\
\hline Greensboro & 71 & 29 & 60 & 40 & 64 & 36 & 56 & 45 \\
\hline Durham & 78 & 22 & 62 & 38 & 70 & 30 & 59 & 41 \\
\hline Raleigh & 68 & 32 & 52 & 48 & 65 & 35 & 52 & 48 \\
\hline Charlotte & 59 & 41 & 40 & 60 & 63 & 37 & 51 & 49 \\
\hline Fayetteville & 72 & 28 & 48 & 52 & 66 & 34 & 47 & 53 \\
\hline Wilmington & 58 & 42 & 43 & 57 & 70 & 30 & 60 & 40 \\
\hline
\end{tabular}

For rural precincts, 54 percent of all votes cast for president were done early, with 46 percent being cast on Election Day. In looking at the mobilization effect of early versus Election Day balloting, the Obama campaign was able to significantly shape its mobilization of supports by garnering significant percentages of ballots cast by Election Day: on average, at least 66 percent of pro-Obama ballots were cast before Election Day in urban precincts; in the suburban precincts, 64 percent came from early balloting for the Democratic presidential candidate; and in rural precincts, 61 percent came from early balloting for Obama. For the Republican McCain, 51 percent of his urban votes came before Election Day, 52 percent of his suburban votes came in early, and 50 percent of his rural votes came in before Election Day. Table 9 details these striking differences, however, in urban and suburban presidential ballots cast either early or on Election Day for both presidential candidates.

With their mobilization effort, Obama's campaign was able to secure a majority of all his North Carolina votes in all urban and suburban precincts prior to Election Day. On the other hand, only 10 out of 16 urban/suburban areas had a majority cast their ballots early for McCain, and in none of the areas did McCain see a greater percentage of his vote coming in through early ballots than Obama did.

Beyond the descriptive analysis of how each voting precinct cast their ballots by partisan and early/non-early voting methods, a linear regression analysis was conducted to analyze the impact of several key factors that may have influenced the voting patterns in the precincts. Due to North Carolina requiring voters to register by party affiliation (Democratic, Republican, or 
Unaffiliated) and disclose their racial classification, various independent variables were constructed to analyze against a dependent variable measured as the percentage of Democratic presidential votes (all vote types) in the 2662 precincts in this study. One important variable that was used was the percentage of registered voters in the precinct who voted early; three other variables that were constructed were dummy variables for whether the precinct was urban (the precinct was inside the major metropolitan city limit), another for whether the precinct was suburban (the precinct was outside the major metropolitan city limit, but inside the Census Bureau's designation of a metropolitan area), and finally whether the precinct was within a majority-minority congressional district. Other independent variables included the percentage of registered voters who are white; the percentage of registered voters who are registered Democratic; and the percentage of registered voters who are registered unaffiliated. Table 10 presents the regression analysis for these variables, sorted by their beta weights.

\section{Table 10. Linear Regression Analysis: Dependent Variable $=$ Percentage of Democratic Presidential Votes Cast in Precinct}

\begin{tabular}{lcccc}
\hline & $\begin{array}{c}\text { B } \\
\text { (Unstandardized } \\
\text { Coefficient) }\end{array}$ & Beta & $\mathrm{t}$ & $\begin{array}{c}\text { Level of } \\
\text { Significance }\end{array}$ \\
\hline $\begin{array}{l}\text { \% of Registered Voters } \\
\text { who are White }\end{array}$ & -.004 & -.488 & -29.95 & .000 \\
$\begin{array}{l}\text { \% of Registered Voters } \\
\text { who are Democratic }\end{array}$ & .005 & .451 & 31.30 & .000 \\
$\begin{array}{l}\text { \% of Registered Voters } \\
\text { who are Unaffiliated }\end{array}$ & .012 & .367 & 37.94 & .000 \\
$\begin{array}{l}\text { Urban Precinct } \\
\text { (Dummy variable) }\end{array}$ & .101 & .209 & 25.32 & .000 \\
$\begin{array}{l}\text { Majority-Minority Precinct } \\
\text { (Dummy variable) } \\
\% \text { of Registered Voters in the }\end{array}$ & .070 & .118 & 10.41 & .000 \\
$\begin{array}{l}\text { Precinct who voted early } \\
\text { Suburban Precinct } \\
\text { (Dummy variable) }\end{array}$ & .125 & .073 & 10.30 & .000 \\
$\begin{array}{l}\text { Constant } \\
\text { N = 2662; Adjusted R }{ }^{2}=.876\end{array}$ & .018 & .043 & 5.49 & .000 \\
Note: Sorted by Beta. & .211 & & 10.731 & .000 \\
\hline
\end{tabular}


The regression results indicate that the racial composition of the precinct had the strongest impact on a precinct's percentage of the Democratic presidential vote. The higher the white percentage in the precinct, the lower the Democratic presidential vote percentage. Partisan affiliation affected the vote in the expected direction, as did the percentage of unaffiliated voters in the precinct. Urban precincts had higher levels of Democratic presidential vote, as did those precincts that were majority-minority as well. Most important for this study, the percentage of registered voters in the precinct who voted early also had a positive relationship with the dependent variable, as did whether the precinct was located in a suburb or not.

\section{Conclusion}

By comparing and contrasting the level of increased voter turnout in urban, suburban and rural precincts, particularly through the use of early/ non-Election Day voting methods, this study provides some further understanding of the role that location plays in electoral behavior, as well as the means by which voters cast their ballots. Based on the descriptive analysis, many of the urban and suburban precincts saw different partisan results in terms of getting voters out early rather than waiting to Election Day. Further investigation as to whether partisan-registered voters cast their ballots early versus unaffiliated voters would help to further clarify whether early voters are motivated by attitudinal distinctions, as Stein (1998) would contend, or whether early voting is due more to demographic characteristics of the voter. It appears that the mobilization hypothesis, as developed by Oliver (1996), did have an impact, but in the opposite political party direction. With the emphasis on grass-roots level mobilization by the Obama campaign, the effect seems to be rather dramatic in some areas for the Democrats when compared to the Republican results. The regression analysis indicates that the factor of race did have an impact on the percentage of Democratic votes in the precinct, along with partisanship, location, and whether a precinct saw higher levels of early voting. By utilizing precinct-level analysis, this study contributes to the continuing study of mobilization in campaigns and elections, as well as the issue of voting behavior in urban, suburban, and rural areas in a competitive state. 
APPENDIX

States that Allow Absentee/Early Voting

\begin{tabular}{|c|c|c|}
\hline State & Availability & Period Early/Absentee Voting Allowed \\
\hline Alaska & Available & 15 days prior to Election Day \\
\hline Arizona & Available & 33 days \\
\hline Arkansas & Available & 15 days prior to Election Day \\
\hline California & Available & Available \\
\hline Colorado & Available & 10 days prior to primary; 15 days prior to general \\
\hline DC & Available & 15 days prior to Election Day \\
\hline Delaware & Available & Available \\
\hline Florida & Available & 15 days prior to Election Day \\
\hline Georgia & Available & Week prior to Election Day \\
\hline Hawaii & Available & Available as in-person absentee \\
\hline Illinois & Available & 22 nd day through 5 th day prior to election \\
\hline Indiana & Available & 29 days prior up to $12 \mathrm{PM}$ on day before Election Day \\
\hline Iowa & Available & $\begin{array}{l}40 \text { days prior to Election Day up to Monday before } \\
\text { Election Day }\end{array}$ \\
\hline Kansas & Available & Available \\
\hline Kentucky & Available & $\begin{array}{l}12 \text { or more working days prior to Election Day; must } \\
\text { meet criteria }\end{array}$ \\
\hline Louisiana & Available & Set by registrar; typically week prior to election \\
\hline Maine & Available & $30-45$ days prior to Election Day \\
\hline Massachusetts & Available & $2-3$ weeks prior with valid reason \\
\hline Minnesota & Available & 30 days with excuse \\
\hline Missouri & Available & Early voting done through absentee \\
\hline Montana & Available & 30 days prior \\
\hline Nebraska & Available & $\begin{array}{l}35 \text { days prior to Election Day; up to Monday prior to } \\
\text { Election Day }\end{array}$ \\
\hline Nevada & Available & Available \\
\hline New Jersey & Available & Available through absentee balloting \\
\hline New Mexico & Available & 28th day before election \\
\hline New York & Available & 32 days before election \\
\hline North Carolina & Available & 3rd Thursday to Saturday prior to Election Day \\
\hline North Dakota & Available & Available \\
\hline Ohio & Available & Typically 35 days before election via absentee \\
\hline Oklahoma & Available & $\begin{array}{l}\text { Friday and Monday before General Election; also on } \\
\text { Saturday with fed elections }\end{array}$ \\
\hline Oregon & Available & Mail-in process \\
\hline Pennsylvania & Available & Available through absentee balloting \\
\hline South Carolina & Available & May cast when absentee request is submitted \\
\hline South Dakota & Available & Done prior to Election Day via absentee ballot \\
\hline Tennessee & Available & 20 days prior and ends 5 days prior to General Election \\
\hline Texas & Available & $\begin{array}{l}\text { Starts } 17 \text { days prior and ends } 4 \text { days prior to General } \\
\text { Election }\end{array}$ \\
\hline Utah & Available & Available up to day before General Election \\
\hline Vermont & Available & 30 days prior \\
\hline Virginia & Available & $\begin{array}{l}\text { Excuse required; } 45 \text { days to } 3 \text { days prior to General } \\
\text { Election }\end{array}$ \\
\hline
\end{tabular}


APPENDIX (continued)

\begin{tabular}{lll}
\hline State & Availability & Period Early/Absentee Voting Allowed \\
\hline Washington & Available & Available \\
West Virginia & Available & 20 days prior and ends 3 days prior to General Election \\
Wisconsin & Available & In-person absentee voting \\
Wyoming & Available & $\begin{array}{l}\text { 40 days prior to Election Day up to Monday before } \\
\text { Election Day }\end{array}$ \\
Alabama & Not available & Not available \\
Connecticut & Not available & Not available \\
Idaho & Not available & Not available \\
Maryland & Not available & Not available \\
Michigan & Not available & Not available \\
Mississippi & Not available & Early voting not available; may vote by absentee with \\
& Noxcuse criteria \\
New Hampshire & Not available & Not available \\
Rhode Island & Not available & Not available \\
Source: League of Women Voters website.
\end{tabular}

\section{NOTES}

${ }^{1}$ Libertarian is also an option to register for in North Carolina, but this was excluded from the analysis at this point.

${ }^{2}$ Lee County was the only county not to report either their election results in such a way as to analyze the votes cast by early or Election Day; a rural county with only six precincts, this one county was excluded from the analysis.

\section{REFERENCES}

Abramson, Paul R., John H. Aldrich, and David W. Rohde. 2007. Change and Continuity in the 2004 and 2006 Elections. Washington, DC: Congressional Quarterly Press.

Abramowitz, Alan, and Kyle Saunders. 2005. Why Can't We All Just Get Along? The Reality of a Polarized America. The Forum 3(2):1.

Barreto, Matt A., Matthew J. Streb, Mara Marks, and Fernando Guerra. 2006. Do Absentee Voters Differ From Polling Place Voters? Public Opinion Quarterly 70(2):224234.

Bartels, Larry. 2006. What's the Matter with What's the Matter with Kansas? Quarterly Journal of Political Science 1(2):201-226.

Bishop, Bill, with Robert G. Cushing. 2008. The Big Sort: Why the Clustering of LikeMinded America Is Tearing Us Apart. New York: Houghton Mifflin Company.

Campbell, Angus, Philip E. Converse, Warren E. Miller, and Donald E. Stokes. 1980. The American Voter. Chicago: University of Chicago Press.

CNN website. Local Exit Polls. http://www.cnn.com/ELECTION/2008/results/polls/ \#val=USP00p3. Accessed 2-20-10. 
Dreier, Peter, John Mollenkopf, and Todd Swanstrom. 2004. Place Matters: Metropolitics for the Twenty-first Century. Lawrence: University Press of Kansas.

Dubin, Jeffrey A., and Gretchen A. Kalsow. 1996. Comparing Absentee and Precinct Voters: A View Over Time. Political Behavior 18(4):369-392.

Federal Election Commission. 1994. Early Voting. Washington, DC: U.S. Government Printing Office.

Fiorina, Morris P., Samuel J. Abrams, and Jeremy C. Pope. 2010. Culture War? The Myth of a Polarized America, 3rd ed. Washington, DC: Longman.

Flanigan, William H., and Nancy H. Zingale. 2010. Political Behavior of the American Electorate, 12th ed. Washington, DC: Congressional Quarterly Press.

Francia, Peter L., and Jody Baumgartner. 2005-06. Victim or Victor of the 'Culture War?' How Cultural Issues Affect Support for George W. Bush in Rural America. American Review of Politics 26(Winter):349-367.

Gainsborough, Juliet F. 2001. Fenced Off: The Suburbanization of American Politics. Washington, DC: Georgetown University Press.

Gainsborough, Juliet F. 2005. Voters in Context: Cities, Suburbs, and Presidential Vote. American Politics Research 33(3):435-461.

Gimpel, James G., and Kimberly A. Karnes. 2006. The Rural Side of the Urban-Rural Gap. PS: Political Science \& Politics 39(3):467-472.

Gimpel, James G., and Jason E. Schuknecht. 2004. Patchwork Nation: Sectionalism and Political Change in American Politics. Ann Arbor: University of Michigan Press.

Hill, David Lee. 2006. American Voter Turnout: An Institutional Perspective. Boulder, CO: Westview Press.

Karp, Jeffrey A., and Susan A. Banducci. 2001. Absentee Voting, Participation, and Mobilization. American Politics Research 29(2):183-195.

Key, V.O., Jr. 1949 (1986). Southern Politics in State and Nation. Knoxville: University of Tennessee Press.

Knotts, H. Gibbs. 2005. Grassroots Republicanism: Evaluating the Trickle Down Realignment Theory in North Carolina. Politics \& Policy 33:1-17.

League of Women Voters. Vote411.org website.

Lieske, Joel. 1989. The Political Dynamics of Urban Voting Behavior. American Journal of Political Science 33(1):150-174.

McCarty, Nolan, Keith T. Poole, and Howard Rosenthal. 2006. Polarized America: The Dance of Ideology and Unequal Riches. Cambridge, MA: Massachusetts Institute of Technology Press.

McGirr, Lisa. 2001. Suburban Warriors: The Origins of the New American Right. Princeton, NJ: Princeton University Press.

McKee, Seth. 2007. Rural Voters in Presidential Elections, 1992-2004. The Forum $5(2): 1-24$.

McKee, Seth, and Daron R. Shaw. 2003. Suburban Voting in Presidential Elections. Presidential Studies Quarterly 33(1):125-144.

McKee, Seth, and Jeremy M. Teigen. 2009. Probing the Reds and Blues: Sectionalism and Voter Location in the 200 and 2004 U.S. Presidential Elections. Political Geography 28:484-495.

Nicholson-Crotty, S., and K.J. Meier. 2002. Size Doesn't Matter: In Defense of Single State Studies. State Politics and Policy Quarterly 2:411-422.

Neely, Grant W., and Lilliard E. Richardson, Jr. 2001. Who is Early Voting? An Individual Level Examination. Social Science Journal 38:381-393.

Oliver, J. Eric. 1996. The Effects of Eligibility Restrictions and Party Activity on Absentee Voting and Overall Turnout. American Journal of Political Science 40:498-513. 
Oliver, J. Eric. 2001. Democracy in Suburbia. Princeton, NJ: Princeton University Press.

Oliver, J. Eric. 2003. Suburban and Metropolitan Politics. In Cities, Politics and Policy: A Comparative Analysis, ed. J.P. Pelissero. Washington, DC: Congressional Quarterly Press.

Oliver, J. Eric, and Shang E. Ha. 2007. Vote Choice in Suburban Elections. American Political Science Review 101(3):393-408.

Oppenheimer, Bruce I. 2005. Deep Red and Blue Congressional Districts: The Causes and Consequences of Declining Party Competitiveness. In Congress Reconsidered, 8th ed., eds. Lawrence C. Dodd and Bruce I. Oppenheimer. Washington, DC: Congressional Quarterly Press.

Panagopoulos, Costas, and Peter L. Francia. 2009. Grassroots Mobilization in the 2008 Presidential Election. Journal of Political Marketing 8(4):315-333.

Patterson, Samuel C., and Gregory A. Caldeira. 1985. Mailing in the Voter: Correlates and consequences of absentee voting. American Journal of Political Science 29: 766-788.

Plouffe, David. 2009. The Audacity to Win: The Inside Story and Lessons of Barack Obama's Historic Victory. New York: Viking.

Rosenstone, Steven J., and J.M. Hansen. 1993. Mobilization, Participation, and Democracy in America. New York: Macmillan.

Schaller, Thomas F. July 1, 2008. The South Will Fall Again. The New York Times. http://www.nytimes.com/2008/07/01/opinion/01 schaller.html. Accessed 2-20-10.

Stein, Robert M. 1998. Early Voting. The Public Opinion Quarterly 62(1):57-69.

Stein, Robert M., and Patricia A. Garcia-Monet. 1997. Voting Early but Not Often. Social Science Quarterly 78(3):657-671.

Teixeira, Ruy, ed. 2008. Red, Blue and Purple America: The Future of Election Demographics. Washington, DC: Brookings Institute Press.

Thomas, G. Scott. 1998. The United States of Suburbia: How the Suburbs Took Control of America and What They Plan to Do With It. New York: Prometheus.

Toner, Robin. July 2, 2004. The 2004 Campaign: The Voters; Bush and Kerry Campaigns Vying for Rural Supporters. The New York Times 14: 1.

Wirt, Frederick M., Benjamin Walter, Francine F. Rabinovitz, and Deborah R. Hensler. 1971. On the City's Rim: Politics and Policy in Suburbia. Lexington, MA: D.C. Heath \& Company. 